\title{
МОРФОФУНКЦІОНАЛЬНІ ЗМІНИ В ЛЕГЕНЯХ ТА ПЕЧІНЦІ У РАННІЙ ПЕРІОД ПІСЛЯ ТРАВМАТИЧНОГО УРАЖЕННЯ М'ЯЗІВ В ЕКСПЕРИМЕНТІ
}

\author{
๑В. Г. Дживак, І. М. Кліщ, Т. В. Дацко, О. І. Хлібовська \\ Тернопільський національний медичний університет імені І. Я. Горбачевського МОз України
}

\begin{abstract}
РЕзюмЕ. Актуальним питанням сьогодення $€$ травматизм, який залишається актуальною проблемою сучасної медицини, оскільки серед постраждалих із травмами відзначаються високі рівні інвалідності та смертності.

Мета - вивчити особливості морфологічних змін у легенях та печінці при травматичному ураженні м'язів в експериментальному дослідженні.

Матеріал і методи. Динаміку морфологічних змін досліджували на експериментальній моделі травматичного ушкодження м'язів у 60 дорослих нелінійних щурів, які були поділені на дві групи: інтактну та дослідну. Досліджували морфологічні зміни в тканинах легень та печінки в ранній посттравматичний період на першу та сьому доби.

Результати. При гістологічному дослідженні тканин печінки та легень на першу добу посттравматичного періоду виявлено структурні зміни, які проявлялися вираженими розладами кровообігу з наступним розвитком дистрофічно-некротичних змін, які досягали максимуму на сьому добу експерименту.

Висновки. При травматичному ураженні м'язів у експериментальних тварин структурні зміни в печінці та легенях починають розвиватись уже з першої доби експерименту, тривають упродовж усього періоду досліджень і проявляються вираженими розладами кровообігу та розвитком дистрофічно-некротичних змін, особливо в епітеліальних структурах, досягаючи максимуму на сьому добу.
\end{abstract}

КлючовІ СлОВА: травматичне ушкодження м'язів, печінка, легені.

Вступ. Актуальною проблемою медицини залишаються множинні та поєднані травматичні ушкодження [1], що становить не тільки медичну а й важливу соціальну проблему. В Україні щороку травми різного ступеня тяжкості отримує близько $10 \%$ населення. За даними ВООЗ, серед причин смертності травми посідають третє, а серед населення до 40 років - перше місце. Незважаючи на те, що потерпілі з політравмою складають 8-10\% від усіх, що поступають на стаціонарне лікування, саме на них припадає до 68 \% летальних випадків [3]. При цьому смертність від нещасних випадків і травм постійно зростає - в середньому на $1 \%$ щорічно [2, 3], що $є$ свідченням недостатньої ефективності надання медичної допомоги таким хворим.

Професійний спорт часто пов'язаний з ризиком виникнення травм. Багато видів спорту $\epsilon$ надзвичайно травматичними, наприклад футбол, регбі, хокей, баскетбол, бокс, боротьба й інші бойові мистецтва. Кількість спортивних травм постійно збільшується і на сьогодні набула загрозливих розмірів. У різних країнах світу кількість травм у спорті коливається в межах 10-17 \% всіх пошкоджень. Для нижніх кінцівок найбільш травмонебезпечним видом спорту $\epsilon$ футбол, де загальна кількість пошкоджень досягає 76,7 \%, для верхніх - спортивна гімнастика з показником 54,5\% [4].

Залишаються недостатньо вивченими закономірності розвитку функціональних та органічних порушень внутрішніх органів, формування системної запальної відповіді в залежності від важкості та тривалості травми. Вивчення цього питання має не тільки теоретичне, а й практичне значення, що дозволить удосконалити ранню діагностику та зменшити небажані побічні ускладнення.

Мета - вивчити особливості морфологічних змін у легенях та печінці при травматичному ураженні м'язів в експериментальному дослідженні.

Матеріал і методи дослідження. Динаміку морфологічних змін досліджували на експериментальній моделі травми. Експериментальне дослідження виконано на 60 дорослих нелінійних білих щурах масою 180-210 г, яких утримували на стандартному раціоні віварію. Тварин було поділено на дві групи: перша група - інтактні тварини (10 щурів), друга група - тварини з травматичним ураженням м'язів стегна (50 щурів). Тваринам дослідної групи під тіопентал-натрієвим наркозом (40 мг/кг маси) за допомогою ударного механізму моделювали травму стегнового м'яза.

Матеріал для гістологічного дослідження отримували на 1-шу і 7-му доби після виведення тварин з експерименту шляхом декапітації під тіопенталовим наркозом. Матеріалом для морфологічних та морфометричних досліджень стали фрагменти легені, печінки. Для здійснення гістологічного дослідження матеріал (фрагменти легені, печінки) фіксували в 10 \% розчині забуференого нейтрального формаліну. Подальше проведення гістологічних препаратів здійснювали згідно з загальноприйнятими методиками [5]. Виготовлення серійних парафінових зрізів товщиною 4-6 мкм проводили за допомогою санного мікротома. Фарбування препаратів здійснювали гематоксиліном та еози- 
Огляди літератури, оригінальні дослідження, погляд на проблему, випадок з практики, короткі повідомлення ном. Вивчали структуру паренхіматозних органів у нормі, а також характер морфологічних змін після травми. Для фотодокументації зображення з гістологічних препаратів виводили на монітор комп'ютера за допомогою мікроскопа Nicon eclipse $\mathrm{C}$ та цифрової відеокамери (Digital Camera SCMOS) з використанням програмного забезпечення ToupWiev при різних збільшеннях.

Робота виконана на базі кафедри патологічної фізіології, патологічної анатомії з секційним курсом та судовою медициною центральної науково-дослідної лабораторії (свідоцтво про атестацію № 001/18 від 26 вересня 2018 року) та міжкафедральної навчально-дослідної лабораторії (свідоцтво про атестацію № 132/17 видане 29 грудня 2017 року) Тернопільського національного медичного університету імені І. Я. Горбачевського МОЗ України.

При роботі з тваринами дотримувались правил поводження з експериментальними тваринами згідно з директивою Ради ЄC 2010/63/EU про дотримання постанов, законів, адміністративних положень Держав ЄС з питань захисту тварин, які використовуються з науковою метою $[6,7]$.

Результати й обговорення. При травматичному ураженні м'язів ранніми та поширеними змінами в легенях на першу добу були виражені розлади кровообігу. Мало місце нерівномірне кровонаповнення судин із перевантаженням венозного русла. Наявність помірних застійних явищ призводила до периваскулярного набряку (рис. 1), збільшуючи площу строми. Відмічається потовщення міжальвеолярних перетинок через повнокров'я судин. Лімфо-плазмоцитарна інфільтрація була дрібновогнищевою. Окремі міжальвеолярні перетинки розривались, що потенціювало формування дистелектазів.

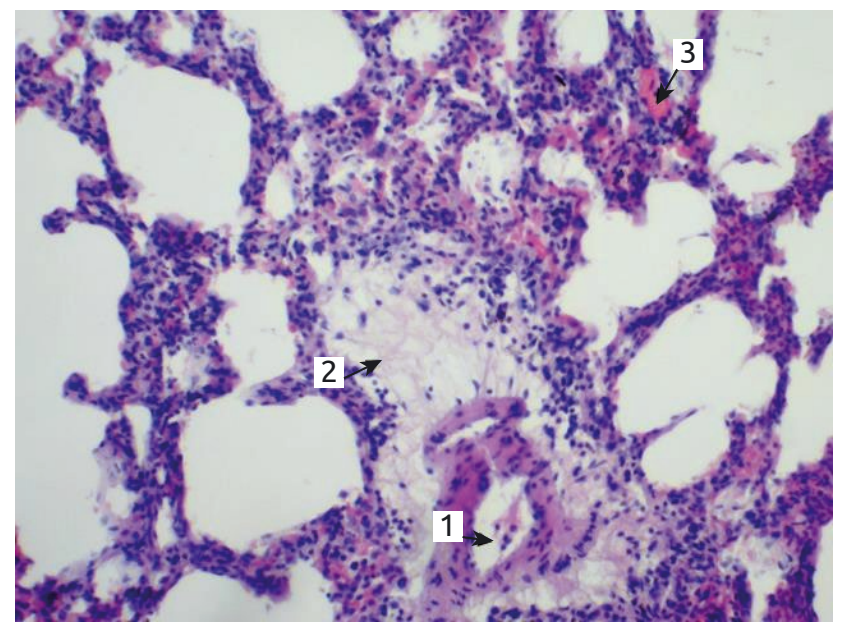

Рис. 1. Структура легені тварини на першу добу після травматичного ушкодження м'язів: 1 - судина; 2 - виражений периваскулярний набряк; 3 - часткове повнокров'я судин дрібного калібру. Забарвлення гематоксиліном та еозином. $\times 100$.

Бронхіоли дещо спазмувались, в їх просвітах візуалізувалась незначна кількість ексудату. Перибронхіолярні ділянки мали звичайну структуру із мінімальною клітинною інфільтрацією.

На сьому добу експерименту в легенях різко збільшувалось кровонаповнення судин переважно дрібного калібру. Міжальвеолярні проміжки потовщувались, переважно через дрібновогнищевий еритродіапедез або помірний периваскулярний набряк (рис. 2). Епітелій при цьому змінювався мало. Просвіти альвеол були вільними від ексудату та клітинних елементів.

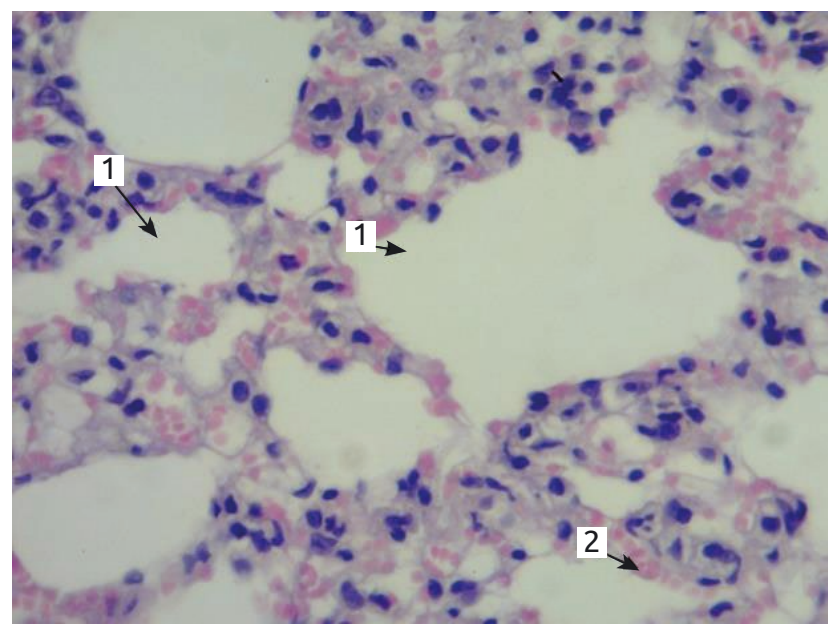

Рис. 2. Структура легені тварини на сьому добу після травматичного ушкодження м'язів: 1 - ділянки дистелектазів; 2 - еритродіапедез. Забарвлення гематоксиліном та еозином. $\times 200$.

Бронхіоли спазмувались, їх просвіти різко звужувались (рис. 3). У перибронхіолярних ділянках строми візуалізувалась помірна кількість лімфо- та гістіоцитів.

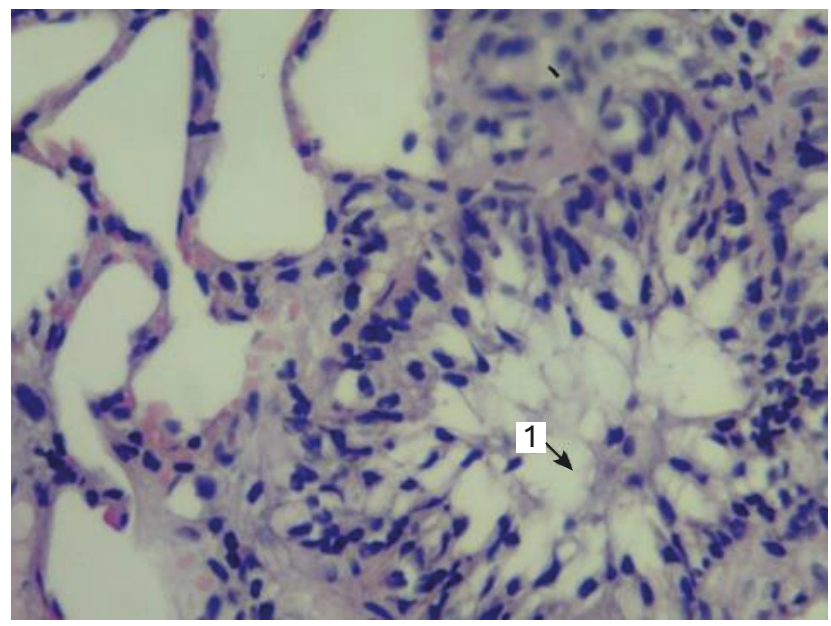

Рис. 3. Структура легені тварини на сьому добу після травматичного ушкодження м'язів: 1 - спазм бронхіол. Забарвлення гематоксиліном та еозином. $\times$ 200. 
Огляди літератури, оригінальні дослідження, погляд на
у результаті аналізу морфологічних змін у тканині печінки на першу добу після експериментального ураження м'язів встановлено наростання застійних явищ, що проявлялось розширенням та повнокров'ям центральних вен (рис. 4). При цьому синусоїди не розширювались, просвіти переважно були вільними від еритроцитів або містили незначну їх кількість. Незначна макрофагальна інфільтрація візуалізувалась лише центролобулярно. Гепатоцити зберігали свою балкову організацію та міжклітинні контакти. Частина гепатоцитів, переважно середньої третини часточки, мала ознаки балкової дистрофії (рис. 4).

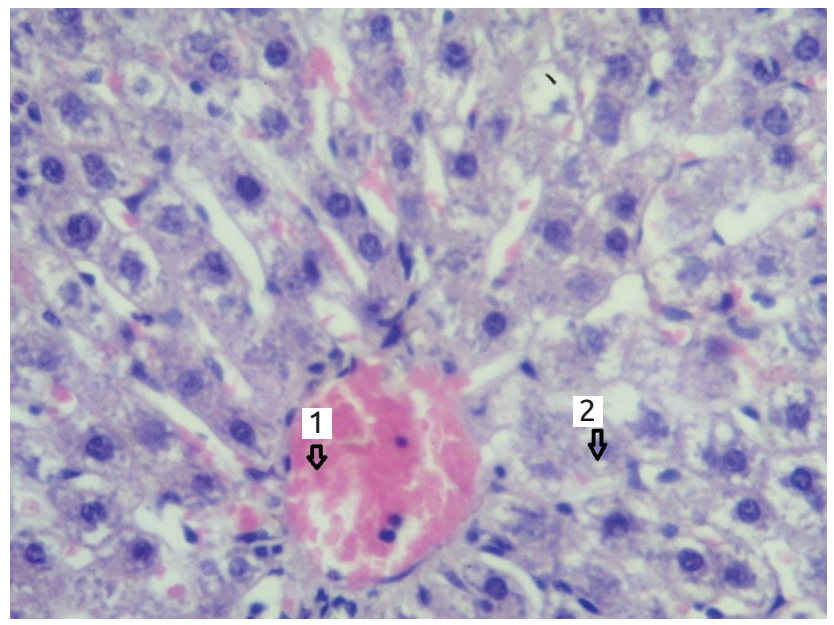

Рис. 4 Структура печінки тварини на першу добу після травматичного ушкодження м'язів: 1 - розширення центральної вени; 2 - дистрофічні зміни. Забарвлення гематоксиліном та еозином. $\times 200$.

Переважна більшість гепатоцитів містила практично незмінені ядра. Портальні тракти змінювались мало, повнокров'я судин було незначним, периваскулярний набряк не візуалізувався, лімфо-гістіоцитарна інфільтрація була мінімальною (рис. 4). Ознак холестазу не виявлено.

На сьому добу експерименту в печінці продовжували наростати і поглиблюватись застійні яви-

\section{ЛІТЕРАТУРА}

1. Гур'єв С. О. Клініко-епідеміологічна характеристика постраждалих з інфекційними ускладненнями політравми внаслідок ДТП / С. О. Гур'єВ, П. В. Танасієнко, С. П. Сацик // Медицина сьогодні і завтра. - 2012. № 1. - C. 54.

2. World Health Organization (WHO) Injuries and violence: the facts. Geneva, Switzerland: WHO, 2014. - URL : http://apps.who.int/iris/bitstream/handle/10665/ 149798/9789241508018_eng.pdf;jsessionid=C29B7C48D8 3C99FC720F5F318FBF67C 8 ? sequence $=1$

3. Chrysou K. Lessons from a large trauma center: impact of blunt chest trauma in polytrauma patients - still a relevant problem? / K. Chrysou // Scandinavian Journal of Trauma, Resuscitation and Emergency Medicine. - 2017. Vol. 25, No. 1. - P. 42. роблему, випадок з практики, короткі повідомлення ща, що проявлялось розширенням центральних вен, розширенням та повнокров'ям синусоїдів. В їх просвітах візуалізувалась значна кількість еритроцитів. Балкова організація гепатоцитів порушувалась, міжклітинні контакти зберігались частково. Мало місце наростання дистрофічних змін у гепатоцитах, переважно гіаліново-крапельної та гідропічної дистрофії (рис. 5).

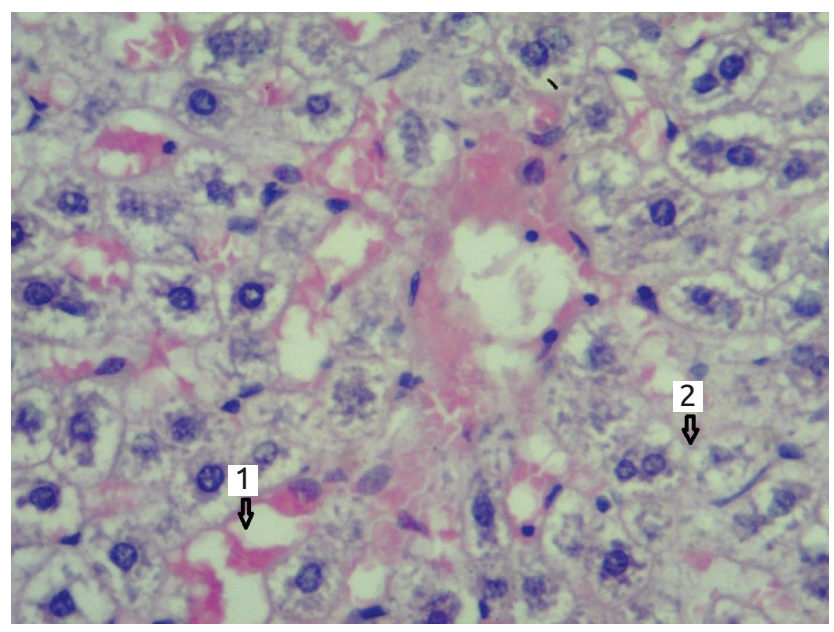

Рис. 5. Печінка тварини на сьому добу після травматичного ушкодження м'язів: 1 - повнокров'я синусоїдів; 2 - виражені дистрофічні зміни в гепатоцитах. Забарвлення гематоксиліном та еозином. $\times 200$.

Таким чином, гістологічне дослідження печінки експериментальних тварин на першу добу експерименту встановило початок розвитку морфологічних змін їі структури, а на сьому - різке зростання ураження її паренхіми.

Висновок. При травматичному ураженні м'язів в експериментальних тварин структурні зміни в печінці та легенях починають розвиватись уже $з$ першої доби експерименту упродовж усього періоду досліджень і проявляються вираженими розладами кровообігу та розвитком дистрофічнонекротичних змін, особливо в епітеліальних структурах, досягаючи максимуму на сьому добу.

4. Йоргенсен У. Роль правил и судейства в профилактике травм / У. Йоргенсен // Спортивные травмы. Основные принципы профилактики и лечения. - Киев : Олимп. лит, 2002. - С. 184-189.

5. Методики морфологічних досліджень: монографія / М. М. Багрій, В. А. Діброва, О. Г. Попадинець, І. М. Грищук ; за ред. М. М. Багрія, В. А. Діброви. - Вінниця : Нова книга, 2016. -238 с.

6. Directive 2010/63/EU of the European Parliament and of the Council of 22 September 2010 on the protection of animals used for scientific purposes // Official Journal of the European Union. - 2010. - L276. - P. 33-79.

7. Guide for the care and use of laboratory animals. 8th ed. - Washington : The National Academies Press, 2011. -246 p. 
Огляди літератури, оригінальні дослідження, погляд на проблему, випадок з практики, короткі повідомлення REFERENCES

1. Huriev, S.,Tanasiienko, P., \& Satsik, S. (2012). Klinikoepidemiolohichna kharakterystyka postrazhdalykh z infektsiinymy uskladnenniamy politravmy vnaslidok DTP [Clinical and epidemiological characteristics of victims with infectious complications of polytrauma due to road accidents]. Medystyna sohodni i zavtra - Medicine Today and Tomorrow, 1, 54 [in Ukrainian].

2. (2014). World Health Organization (WHO) Injuries and violence: the facts. Geneva, Switzerland: WHO. Retrieved from: http://apps.who.int/iris/bitstream/handle/10665/149798/9789241508018_eng.pdf;jsessionid= C29B7C48D83C99FC720F5F318FBF67C8?sequence $=1$

3. Chrysou, K. (2017). Lessons from a large trauma center: impact of blunt chest trauma in polytrauma patients still a relevant problem? Scandinavian Journal of Trauma, Resuscitation and Emergency Medicine, 25 (1), 42.
4. Yorgensen, U. (2002). Rol pravil i sudeystva v profilaktike travm [The role of rules and refereeing in injury prevention]. Sportivnye travmy. Osnovnye printsipy profilaktiki i lecheniya - Sport Injuries. Basic Principles of Prevention and Treatment. Kyiv: Olimpus. Lit. [in Ukrainian].

5. Bahrii, M., Dibrova, V., Popadynets, O., \& Hryshchuk, I. (2016). Metidyky morfolohichnykh doslidzhen: monohrafiia [Methods of morphological researches: monograph]. Bahrii, M., \& Dibrova, V. (Eds.). Vinnytsia: Nova Knyha [in Ukrainian].

6. (2010). Directive 2010/63/EU of the European Parliament and of the Council of 22 September 2010 on the protection of animals used for scientific purposes. Official Journal of the European Union, 276, 33-79.

7. (2011). Guide for the care and use of laboratory animals. 8th ed. Washington: The National Academies Press.

\section{МОРФОФУНКЦИОНАЛЬНЫЕ ИЗМЕНЕНИЯ В ЛЕГКИХ И ПЕЧЕНИ В РАННИЙ ПЕРИОД ПОСТТРАВМАТИЧЕСКОГО ПОРАЖЕНИЯ МЫШЦ В ЭКСПЕРИМЕНТЕ}

\section{๑В. Г. Дживак, И. Н. Клищ, Т. В. Дацко, О. И. Хлибовская}

Тернопольский национальный медицинский университет имени И. Я. Горбачевского МОз Украины

РЕЗЮМЕ. Актуальным на сегодня вопросом является травматизм, который остается актуальной проблемой современной медицины, поскольку среди пострадавших с травмами отмечаются высокие уровни инвалидности и смертности.

Цель - изучить особенности морфологических изменений в легких и печени при травматическом поражении мышц в экспериментальном исследовании.

Материал и методы. Динамику морфологических изменений исследовали на экспериментальной модели травматического повреждения мышц у 60 взрослых нелинейных крыс, которые были поделены на две группы: интактную и исследовательскую. Исследовали морфологические изменения в тканях легких и печени в ранний посттравматический период на первые и седьмые сутки.

Результаты. При гистологическом исследовании тканей печени и легких в первые сутки посттравматического периода выявлены структурные изменения, которые проявлялись выраженными расстройствами кровообращения и последующим развитием дистрофически-некротических изменений, которые достигали максимума на седьмые сутки эксперимента.

Выводы. При травматическом поражении мышц у экспериментальных животных структурные изменения в печени и легких начинают развиваться уже с первых суток эксперимента на протяжении всего периода исследований и проявляются выраженными расстройствами кровообращения и развитием дистрофически-некротических изменений, особенно в эпителиальных структурах, достигая максимума на седьмые сутки.

КЛЮчЕВЫЕ СЛОВА: травматическое повреждение мышц; печень; легкие.

\section{MORPHOFUNCTIONAL CHANGES IN LUNGS AND LIVER IN THE EARLY PERIOD AFTER TRAUMATIC MUSCLE INJURY IN THE EXPERIMENT}

\section{@V. H. Dzhyvak, I. M. Klishch, T. V. Datsko, O. I. Khlibovska \\ I. Horbachevsky Ternopil National Medical University}

SUMMARY. An urgent issue today is traumatism, which remains an urgent problem in modern medicine, as there are high levels of disability and mortality among trauma victims.

The aim - to study peculiarities of morphological changes in lungs and liver in traumatic muscle injury in experimental study.

Material and Methods. The dynamics of morphological changes were investigated in an experimental model of traumatic muscle injury in 60 adult nonlinear rats, which were divided into two groups: intact and experimental. Morphological changes in lung and liver tissues were investigated in the early post-traumatic period for the first and seventh days.

Results and Discussion. Histological examination of liver and lung tissues on the first day of the post-traumatic period revealed structural changes that were manifested by marked circulatory disorders and with subsequent development of dystrophic-necrotic changes, which reached a maximum by the seventh day of the experiment.

Conclusions. In traumatic muscle lesions in experimental animals, structural changes in the liver and lungs begin to develop from the first day of the experiment throughout the study period and are manifested by marked circulatory disorders and the development of dystrophic-necrotic changes, especially in epithelial maxima, reaching maximal structures.

KEY WORDS: traumatic muscle damage; liver; lungs. 